\title{
REGULARARTICLE
}

\section{ANTIBACTERIAL EFFECT OF PERSICARIA THUNBERGII ON STAPHYLOCOCCUS AUREUS}

\author{
MAHESHKUMAR PRAKASH PATIL ${ }^{1 \dagger}$, EUN-SOO NOH ${ }^{1,2^{\dagger}}$, YEONG-AE SEONG ${ }^{{ }^{*}}$, GUN-DO KIM ${ }^{{ }^{*}}$
}

${ }^{1}$ Pukyong National University, College of Natural Sciences, Department of Microbiology, 45 Yongso-ro,

Nam-gu, Busan 48513, Republic of Korea

${ }^{2}$ National Institute of Fisheries Science, Biotechnology Research Division, Busan 48513, Republic of Korea

\begin{abstract}
With the discovery of various antibiotic resistant bacteria, evaluations of antimicrobial activities of natural compounds have been preceded on antibiotic susceptible and resistant microorganisms. Several types of natural compounds have been reported to have similar effects on target microorganisms as compared to the widely used antibiotics. Persicaria thunbergii (Polygonaceae) has been known to have anti-tumoral, anti-angiogenesis, anti-oxidation and anti-inflammation functions. In this study, aerial parts of $P$. thunbergii were extracted using methanol, chloroform, and ethyl acetate to identify possible antibacterial effects. Agar disk diffusion method and time-kill assay were done to evaluate the antibacterial effect of $P$. thunbergii extracts. Two extracts ethyl acetate (EAE), and chloroform (CFE) were tested against Staphylococcus aureus. As a result, the extract from CFE and EAE showed antibacterial effect against $S$. aureus. The extract EAE showed the strongest inhibition effect compared to CFE. These results demonstrate that the EAE extract which originated from $P$. thunbergii can probably play a role as an antibacterial agent.
\end{abstract}

Keywords: Antibacterial effect, Disk diffusion, Persicaria thunbergii, Staphylococcus aureus, time-kill assay

\section{INTRODUCTION}

Development of antibiotic resistance in bacteria is a critical issue in the controlling of infectious diseases $[1,2]$. Therefore, antibacterial agents are needed to be found and apply to control multi-drugs resistant bacteria [3]. There has been growing interests to find antimicrobial compounds with different mechanism of action from natural resources such as plant extracts as an alternative approach to deal with this problem [4]. In recent years, the Staphylococcus aureus has been identified as a resilient and resistant pathogen $[1,4]$. The hospitals outbreak of multi-drug resistant $S$. aureus has been reported worldwide. Only $\sim 20 \%$ of the $S$. aureus strains remain sensitive to penicillin [4], $\sim 60 \%$ of the $S$. aureus clinical isolated strains in United State of America shows resistance to methicillin [5]. The failure of existing antibiotics in controlling the $S$. aureus infections has increased interest in finding an alternative treatment. The natural resource such as medicinal plants plays a significant role in primary healthcare system. The plants extract contains different phytochemicals such as alkaloids, steroids, flavonoids, proteins, tannins, phenolic compounds; and secondary metabolites which plays a defensive work against foreign infectious agents to protect plant.

The Persicaria thunbergii is an herb with $30-100 \mathrm{~cm}$ height and long petioles with wings; belongs to family Polygonaceae. This plant is famous in Korea and China for folk medicinal uses in curing rheumatism, measles and hemorrhage. $P$. thunbergii is a medicinal plant; recently significant activities reported in biomedical applications such as, anti-tumoral [6], isorhamnetin induced-apoptosis [7], anti-oxidation [8], antiinflammation [9], anti-angiogenesis [10], and flavonoids from $P$. thunbergii reported as a acetylcholinesterase inhibitor [11]. However, to date, there is no data on antibacterial activity of $P$. thunbergii on pathogenic bacteria. Thus, the present study aimed to determine the antibacterial activity of $P$. thunbergii different extract on Staphylococcus aureus bacteria.

\section{MATERIALS AND METHODS}

\section{Materials}

The aerial part of $P$. thunbergii was collected from Yangsa, Gyeongnam in Korea. Mueller-Hinton Agar (MHA) and Brain Heart Infusion (BHI) broth were obtained from BD diagnostic, Le Pont De Claix, France. Staphylococcus aureus ATCC6538P was procured from Korean Culture

\section{Received 18 March 2018; Accepted 21 May 2018 \\ †Authors contributed equally \\ *Corresponding Author \\ Gun-do Kim}

Pukyong National University, College of Natural Sciences, Department of Microbiology, 45 Yongso-ro, Nam-gu, Busan 48513, Republic of Korea

Email: mimosung@hanmail.net

( This article is open access and licensed under the terms of the Creative Commons Attribution License (http://creativecommons.org/licenses/by/4.o/) which permits unrestricted, use, distribution and reproduction in any medium, or format for any purpose, even commercially provided the work is properly cited. Attribution - You must give appropriate credit, provide a link to the license, and indicate if changes were made. 


\section{Center of Microorganisms (KCCM).}

\section{Plant material extraction and fractionation}

Sample extract preparation and separation process perform as described previously with minor modifications [9]. In brief, the aerial part of $P$. thunbergii was dried at room temperature and powder was prepared using electric grinder. The prepared powder was soaked in methanol at room temperature, after $4 \mathrm{w}$ residue separated by filtration. The filtrate was concentrated in vacuum condition. After that, methanol extract was fractioned with chloroform using separation funnel. Consequently, ethyl acetate extracts were fractioned using the same method. Each extracts were adsorbed on the silica gel and followed separation by automated flash chromatography system (MPLC; Combifresh-RF. ISCO) and samples dried under vacuum condition.

\section{Disk diffusion assay}

This method was performed as per CLSI guideline description [12]. S. aureus were separately inoculated in tube containing 5 $\mathrm{ml} \mathrm{BHI} \mathrm{broth,} \mathrm{and} \mathrm{incubated} \mathrm{at} 37^{\circ} \mathrm{C}$ for $4 \mathrm{~h}$ in rotary shaking incubator. After incubation, $100 \mu \mathrm{l}$ of each of the bacterial suspension approximately $10^{5} \mathrm{CFU}$. $\mathrm{ml}^{-1}$ were spreaded over the surface of MHA plate using sterile glass spreader. Paper disk ( $8 \mathrm{~mm}$ diameter), were dropped with $10 \mu \mathrm{g}$ penicillin and different concentrations $(1,3$, and $5 \mathrm{mg}$ ) of $P$. thunbergii ethyl acetate extract (EAE) and chloroform extracts (CFE) separately. After that, paper disk placed in four corners on the surface of MHA plates inoculated with bacteria and incubated at $37^{\circ} \mathrm{C}$ for $17 \mathrm{~h}$. After incubation diameter of bacterial growth inhibition surrounding the paper disk called zone of inhibition (ZOI) were measured in $\mathrm{mm}$.

\section{Bacterial viability test}

The $S$. aureus suspension was prepared as mentioned in previous test. Six tubes with $5 \mathrm{ml}$ BHI broth were prepared and inoculated with $S$. aureus suspension. First tube was set as a control, and in second tube $20 \mu \mathrm{l}$ of dimethylsulfoxide (DMSO) was added. After which $20 \mu \mathrm{l}$ of $\mathrm{EAE}$ and $\mathrm{CFE}$ with a concentration 400 and $800 \mu \mathrm{g} . \mathrm{ml}^{-1}$ were added, respectively to each of the remaining tubes. All the tubes were incubated at $37{ }^{\circ} \mathrm{C}$ for $17 \mathrm{~h}$. After that, serial dilutions were prepared from $10^{-1}$ to $10^{-7}$. Then, 100 $\mu \mathrm{l}$ of $10^{-6}$ and $10^{-7}$ dilutions were separately spreaded over the surface of BHI agar in duplicates. All plates after spreading were incubated at $37{ }^{\circ} \mathrm{C}$ for $17 \mathrm{~h}$. The former colonies on the agar plates were counted to determined which samples were to be subjected to time kill assay.

\section{Time kill assay}

Seven tubes with $5 \mathrm{ml}$ BHI broth were prepared. All tubes were inoculated with $S$. aureus. One tube was set as a control, and in another tube $20 \mu$ l of dimethylsulfoxide (DMSO) was added. After which $20 \mu \mathrm{l}$ of EAE and CFE with a concentration $400 \mu \mathrm{g} . \mathrm{ml}^{-1}$ were added to 2 tubes, respectively. The remaining 3 tubes were added with a concentration $400 \mu \mathrm{g} . \mathrm{ml}^{-1}$ of the EAE fractions (EAE1, EAE2, and EAE3) separately. All tubes were incubated at $37^{\circ} \mathrm{C}$ and optical density (OD) at $620 \mathrm{~nm}$ was observed at interval of every $4 \mathrm{~h}$ up to $24 \mathrm{~h}$.

\section{RESULTS AND DISCUSSION}

The $P$. thunbergii extracts were screened for antibacterial susceptibility by disk diffusion method against $S$. aureus, the concentration dependent ZOI were observed against $S$. aureus. Fig.1 (a) indicates ZOI around disk contains (1) Penicillin10 $\mu \mathrm{g},(2,3$, and 4) 1,3 , and $5 \mathrm{mg}$ of EAE respectively, likewise, Fig.1 (b) indicates ZOI around disk contains (1) Penicillin1o $\mu \mathrm{g}(2,3$, and 4), 1, 3, and $5 \mathrm{mg}$ of CFE, respectively. Penicillin shows ZOI (14 mm) smaller than EAE, and CFE. ZOI for EAE were recorded 17, 22, and $24 \mathrm{~mm}$ at concentration per disk was 1,5 and $5 \mathrm{mg}$, respectively. While, ZOI for CFE were observed 22, 23, and $24 \mathrm{~mm}$ at 1, 3 and $5 \mathrm{mg}$ per disk, respectively.

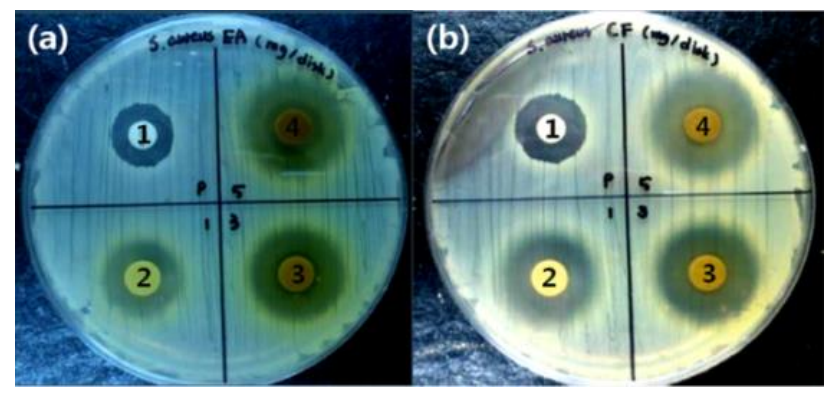

Fig. 1: Zone of inhibition of Persicaria thunbergii extracts (a) Ethyl acetate extract and (b)

Chloroform extract on Staphylococcus aureus

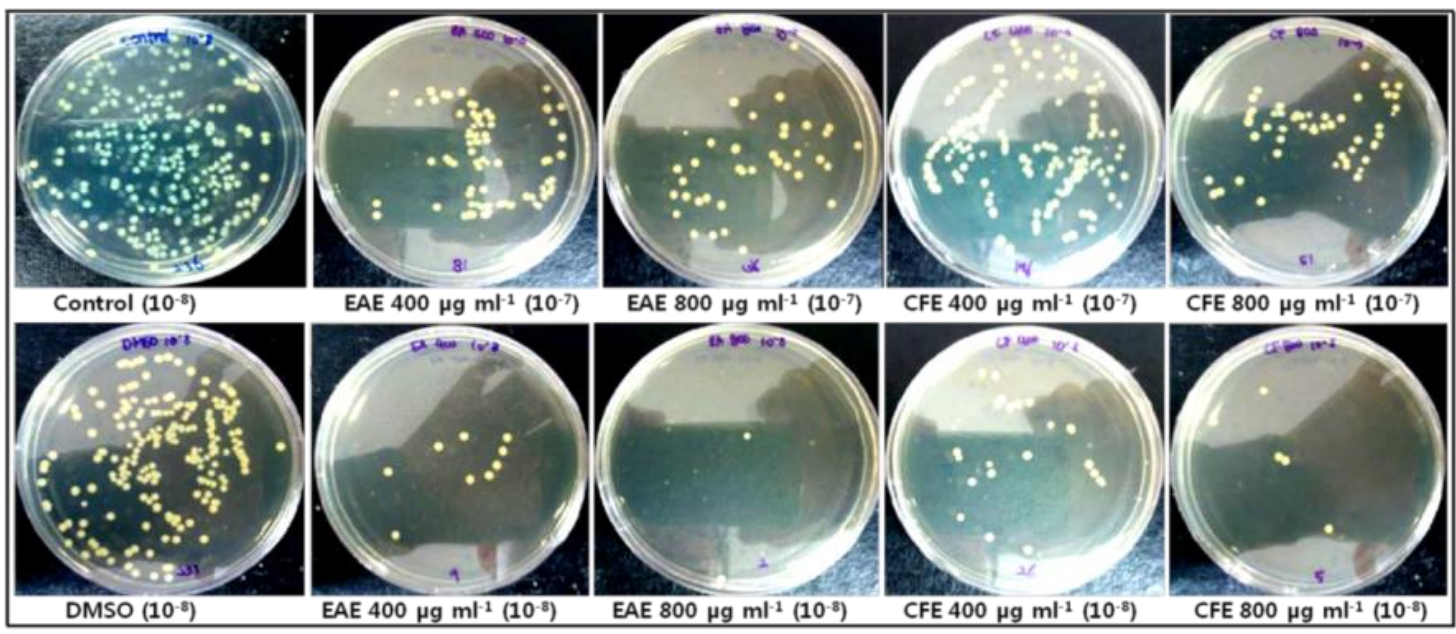

Fig. 2: Persicaria thunbergii extracts exhibits concentration dependent antibacterial susceptibility against Staphylococcus aureus. (DMSO-Dimethylsulfoxide, EAE-Ethyl acetate extract, CFE-Chloroform extract) 
The bacterial viability test was performed against $S$. aureus by spread plate method. The $P$. thunbergii extracts were observed concentration dependent antibacterial activity. EAE and CFE treated bacterial suspension tubes, after incubation were subjected to serial dilution and spreaded on agar surface to develop colonies for determining bactericidal effect. Fig. 2 indicates, Untreated (control) and DMSO containing bacterial suspension $\left(10^{-8}\right)$, EAE, and CFE treated bacterial suspension $\left(10^{-7}, 10^{-8}\right)$ at 400 and $500 \mu \mathrm{g}$. $\mathrm{ml}^{-1}$ concentrations were developed colonies. The number of colonies counted (table 1) and indicated the $S$. aureus were concentration dependent susceptible; EAE shows strong bactericidal effect compared to CFE at both concentrations.

After $P$. thunbergii extracts treated bacterial viability check, $400 \mu \mathrm{g}$. $\mathrm{ml}^{-1}$ EAE and CFE were used to determine the time dependent bactericidal effect. Time kill assay were performed by spectroscopic method. Fig.3 indicates the untreated (control) and DMSO containing bacterial suspension shows time dependent increased absorbance at $600 \mathrm{~nm}$ indicates multiplication of bacteria, comparatively EAE and CFE shows less absorbance. The EAE shows more bacteria killing potential than CFE.

The $P$. thunbergii aerial part contains flavonoids and flavonoids glycosides such as isorhamnetin, quercetin, and shows potential anticancer, antitumor and anti-oxidant activity without any toxic effect on human cells [6, 9-11]. Flavonoids are the good source as an antibacterial agent
[13], and due to non-toxic nature and natural resource $P$. thunbergii extract can be useful as a new antibacterial agent. Other members of genus Persicaria, such as $P$. odorata [14] and P. minor (Huds.) [15] were reported for their potential antimicrobial activity. This is the first reporting for antibacterial potential of $P$. thunbergii against $S$. aureus. Overall, $P$. thunbergii EAE has good antibacterial activity against $S$. aureus, the phytocomposition and exact mechanism behind $S$. aureus growth inhibition needs more detail studies.

\section{CONCLUSION}

In conclusion, plant extracts have great potential as antimicrobial agent. Thus, it can be used in treating of infectious diseases caused by pathogenic bacteria. In this study, extracts of $P$. thunbergii was found to exhibit antibacterial effects on $S$. aureus. However the mechanism of antibacterial properties of $P$. thunbergii extract is still unknown. These findings suggest that the extract from $P$. thunbergii is can be useful in healthcare and medicines as an antibacterial agent.

\section{ACKNOWLEDGEMENT}

This study was financially supported by the Pukyong National University, Republic of Korea (Year 2017).

\section{CONFLICT OF INTERESTS}

No conflict of interest declared

Table 1: Bacterial viability test. $P$. thunbergii EAE and CFE shows concentration dependent $S$. aureus inhibition. (DMSO-Dimethylsulfoxide, EAE-Ethyl acetate extract, CFE-Chloroform extract, and TNTC-Too numerous to count)

\begin{tabular}{|c|c|c|c|c|c|c|}
\hline Dilution & Control & DMSO & $\begin{array}{l}\text { EAE } 400 \mu g . \\
\mathrm{ml}^{-1}\end{array}$ & $\begin{array}{l}\text { EAE } 800 \mu \mathrm{g} . \\
\mathrm{ml}^{-1}\end{array}$ & $\begin{array}{l}\text { CFE } 400 \mu g . \\
\mathrm{ml}^{-1}\end{array}$ & $\begin{array}{l}\text { CFE } 800 \mu g . \\
\mathrm{ml}^{-1}\end{array}$ \\
\hline $10^{-7}$ & TNTC & TNTC & 81 & 36 & 196 & 51 \\
\hline $10^{-8}$ & 236 & 231 & 9 & 2 & 26 & 5 \\
\hline
\end{tabular}

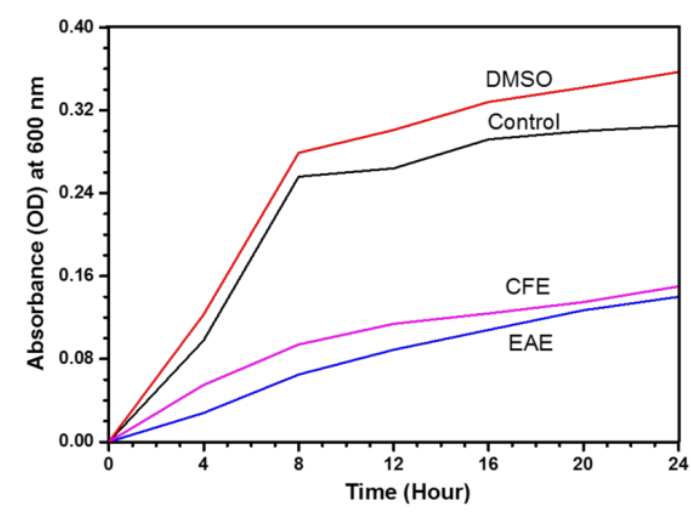

Fig. 3: Time kill assay. Persicaria thumbergii EAE and CFE shows time dependent Staphylococcus aureus inhibition. (DMSO-Dimethylsulfoxide, EAE-Ethyl acetate extract, CFE-Chloroform extract, and TNTC-Too numerous to count) 


\section{REFERENCES}

1. Grundmann H, Aires-de-Sousa M, Boyce J, Tiemersma E. Emergence and resurgence of meticillin-resistant Staphylococcus aureus as a public-health threat. The Lancet. 2006;368(9538):874-885.

2. Lestari ES, Severin JA, Filius PMG, Kuntaman K, Duerink DO, Hadi U, Wahjono H, Verbrugh HA. Antimicrobial resistance among commensal isolates of Escherichia coli and Staphylococcus aureus in the Indonesian population inside and outside hospitals. European Journal of Clinical Microbiology and Infectious Diseases. 2008;27:45.

3. Gould IM. The epidemiology of antibiotic resistance. International Journal of Antimicrobial agents. 2008;32:S2-S9.

4. Bal AM, Gould IM. Antibiotic resistance in Staphylococcus aureus and its relevance in therapy. Expert opinion on pharmacotherapy. 2005;6:2257-2269.

5. Parker MT, Jevons MP. A survey of methicillin resistance in Staphylococcus aureus. Postgraduate medical journal. 1964;40(Suppl):170-178.

6. Oh HM, Kwon BM, Baek NI, Kim SH, Chung IS, Park MH, Park HW, Lee JH, Park HW, Kim EJ, Kim DK. Inhibitory activity of isorhamnetin from Persicaria thunbergii on farnesyl protein transferase. Archives of Pharmacal Research. 2005:28:169-171.

7. Lee H-J, Lee H-J, Lee E-O, Ko S-G, Bae H-S, Kim CH, Ahn K-S, Lu J, Kim SH. Mitochondria-cytochrome C-caspase-9 cascade mediates isorhamnetin-induced apoptosis. Cancer Letters. 2008;270:342-353.

8. Lee K-T, Ku C-H, Eun J-S, Shin T-Y, Lim J-P, Eom D$\mathrm{O}$, Zee OP, Kim D-K. Antioxidative components from the aerial parts of Persicaria thunbergii. JournalPharmaceutical Society Of Korea. 2001;45:611-616.

9. Kim SB, Seong Y, Jang HJ, Kim G-D. The AntiInflammatory Effects of Persicaria thunbergii Extracts on Lipopolysaccharide-Stimulated RAW264. 7 Cells. Journal of Life Science. 2011;21:1689-1697.

10. Lee H-J, Kim K-H, Kim D-K, Yang D-C, Kim S-H. Anti angiogenic effects of isorhamnetin isolated from Persicaria thunbergii. Korean Journal of Plant Research. 2005;8:209-216.

11. Kim SY, Park JY, Park PS, Bang SH, Lee KM, Lee YR, Jang YH, Kim MJ, Chun W, Heo MY, Kwon Y. Flavonoid glycosides as acetylcholinesterase inhibitors from the whole plants of Persicaria thunbergii. Natural Product Science. 2014;20:191-195.

12. CLSI; Clinical and Laboratory Standard Institute. Methods for determining bactericidal activity of antimicrobial agents: Approved guideline, M26-A. 1999, Vol. 19, CLSI, Wayne, PA, USA. https://clsi. org/media/1462/m26a_sample.pdf

13. Cushnie TT, Lamb AJ. Antimicrobial activity of flavonoids. International Journal of Antimicrobial Agents, 2005;26:343-356.

14. Pauzi MR, Hamzah HA, Shah A, Mohd Hassan N, Aminah KS. Antibacterial and antifungal properties of Persicaria odorata leaf against pathogenic bacteria and fungi. In The Open Conference Proceedings Journal. 2013;4:71-74.

15. Abubakar MA, Zulkifli RM, Hassan WNAW, Shariff AHM, Malek NANN, Zakaria Z, Ahmad F. Antibacterial properties of Persicaria minor (Huds.) ethanolic and aqueous-ethanolic leaf extracts. Journal of Applied Pharmaceutical Sciences. 2015;5:50-56. 